\title{
First experience of using favipiravir in the first healthcare worker patient with moderate case of Coronavirus Disease 2019 (COVID-19) at Sulianti Saroso Infectious Disease Hospital, Jakarta, Indonesia: a case report
}

DOI: https://doi.org/10.22435/hsji.v12i1.4879

Pompini Agustina Sitompul, Nina Mariana, Adria Rusli, Titi Sundari, Rosa Marlina, Faisal Matondang, Haruyuki Dewi Faisal, Mohammad Syahril

Sulianti Saroso Infectious Disease Hospital, Jakarta, Indonesia

Corresponding author: Nina Mariana

Email: mynayla09@yahoo.com

Received: March 2, 2021; Revised: May 19, 2021; Accepted: May 31, 2021.

\begin{abstract}
Background: During the early period of the Severe Acute Respiratory Syndrome Coronavirus 2 (SARSCoV-2) pandemic, there was no approved and definitive drug available for the treatment of COVID-19. Favipiravir, chloroquine, hydroxychloroquine was used for re-purposing drugs while their efficacy and safety remained a major concern for healthcare workers. Clinical trial to assess efficacy and safety were ongoing.

Case presentation: We present here the case of a 38-year-old woman, the first case of a healthcare worker diagnosed with COVID-19 who had moderate type, including first experience treatment with favipiravir in Sulianti Saroso Infectious Disease Hospital, Jakarta, Indonesia. We present the clinical characteristics, chest X-ray, clinical laboratory profiles, the treatment process with favipiravir and hydroxychloroquine as well as the clinical outcome of moderate type COVID-19 patient.

Conclusion: This case highlights that considering the use of emergency intervention outside of clinical trial in the COVID-19 population, the informed patient consent has been given and the use of emergency intervention was monitored. (Health Science Journal of Indonesia 2021;12(1):14-9)
\end{abstract}

Keywords: COVID-19, favipiravir, medical worker, case report, Jakarta

\begin{abstract}
Abstrak
Latar belakang: Periode awal pandemi Severe Acute Respiratory Syndrome Coronavirus 2 (SARS$\mathrm{CoV}-2$ ), belum terdapat obat yang disetujui dan pasti tersedia untuk pengobatan COVID-19. Favipiravir, chloroquine, hydroxychloroquine digunakan sebagai obat dengan indikasi baru yang sementara efektifitas dan keamanannya menjadi perhatian para petugas medis.

Penyajian kasus: Disini kami melaporkan kasus wanita umur 38 tahun, merupakan kasus pertama seorang tenaga kesehatan Rumah Sakit terdiagnosis Coronavirus Disease 2019 (COVID-19) dengan penggunaan terapi favipiravir untuk pertama kalinya di Rumah Sakit Pusat Infeksi Sulianti Saroso, Jakarta, Indonesia. Berikut ini kami gambarkan karakteristik klinis, hasil foto thorak, profil laboratorium dan proses terapi menggunakan favipiravir and hidroxychloroquine serta hasil akhir pada kasus COVID-19 derajat sedang.

Kesimpulan: Kasus ini menggaribawahi bahwa pertimbangan penggunaan kegawatdaruratan obat antivirus diluar uji klinis pada populasi pasien COVID-19, pasien telah memberikan persetujuan dan penggunaan obat-obat tersebut dimonitor. (Health Science Journal of Indonesia 2021;12(1):14-9)
\end{abstract}

Kata kunci: Covid-19, favipiravir, tenaga kesehatan, laporan kasus, Jakarta 
In December 2019, an outbreak of pneumonia caused by a novel coronavirus occurred in China, and spread rapidly to other countries. ${ }^{1}$ As of March $2^{\text {nd }} 2020$, The Indonesian Government announced the first confirmed case, followed by reported total 5516 confirmed cases of COVID-19 with 496 deaths $(8.9 \%)$ from across all 34 provinces in April 2020. ${ }^{2}$

In Indonesia, the healthcare workers are greatly affected by the disease. Indonesian Medical Association (IDI) reported that at least 27 doctors have died due to the disease as of May 2020 and others contracted the disease with mild to moderate symptoms. ${ }^{3}$ Preventing healthcare workers infections is important for reducing morbidity and potential mortality, maintaining health system capacity, and reducing secondary transmission. ${ }^{4}$

We need to find a specific treatment against COVID-19. Currently, there are no definitive antiviral drugs. Without effective treatment, moderate patients could convert into severe develop acute respiratory distress syndrome (ARDS) and multi-organ failure. ${ }^{1}$

Research is underway to identify therapeutics for COVID-19, including re-purposing medications. ${ }^{5}$ Favipiravir, an antiviral drug targeting influenza viral RNA-dependent RNA polymerase (RdRP). It selectively inhibits RNA polymerase, which is necessary for viral replication. ${ }^{5}$ Chang Chen et al, showed that favipiravir could be considered as a treatment in moderate COVID-19 patients. ${ }^{1}$ Only a few favipiravir efficacy trials in COVID-19 have been reported in the literature to date, numerous other favipiravir COVID-19 trials are ongoing or as yet unreported. ${ }^{6}$

This case is about a first healthcare worker patient diagnosed with COVID-19 who had moderate type, including the use of favipiravir in Sulianti Saroso Infectious Disease Hospital, Jakarta, Indonesia. At the early period of pandemic, efficacy and safety of favipiravir remained a major concern. The use of emergency intervention outside of clinical trial in COVID-19 population, informed patient's consent has been given and the use of emergency intervention was monitored. ${ }^{7}$ We present the characteristics of the vital signs, chest X-ray, clinical laboratory profiles, the treatment process with favipiravir and hydroxychloroquine as well as the clinical outcome of moderate type of COVID-19 patients who is also a healthcare worker.

\section{CASE PRESENTATION}

On April 13 $3^{\text {th }} 2020$, a 38-year-old woman was admitted to Sulianti Saroso Infectious Disease Hospital, Jakarta, Indonesia, with a history (10 days) of intermittent fever, cough, sore throat, and rhinorrhea, followed by a 4-day-history of shortness of breath. She is a healthcare worker that had a history of taking care of patients with COVID-19 in an isolation ward. She worked 8-hour shifts and commuted between hospital and her home during her duty period.

The patient did not report any underlying medical condition such as diabetes or hypertension. She had a normal body mass index (BMI) and no history of dyslipidemia or hyperuricemia.

During our first clinical evaluation, physical examination revealed that the pulse rate was 110 / minute, blood pressure $107 / 60 \mathrm{~mm} \mathrm{Hg}$, respiratory rate $30 /$ minute, the body temperature $36.2^{\circ} \mathrm{C}$ and $98 \%$ oxygen saturation on ambient air. She required $3 \mathrm{~L} /$ minute of oxygen via nasal cannula. An electrocardiogram (ECG) revealed sinus rhythm with QTc $388 \mathrm{Ms}$. A radiological finding in computed tomography (CT) showed ground-glass opacity, and chest X-ray showed pneumonia lower zone bilateral (Figure 1). Swab test for COVID-19 were taken on April $14^{\text {th }} 2020$, the real-time PCR on nasopharyngeal swab revealed the presence of SARS-CoV-2.

According to the blood test results, white blood cell count was normal $\left(5 \times 10^{\wedge} 3 / \mu \mathrm{L}\right)$, lymphocyte count was $16 \%$, hemoglobin and platelet level were within normal limit, the neutrophil count was $75 \%$, albumin level was decreased to $2.8 \mathrm{~g} / \mathrm{L}$, and ferritin was slightly elevated to $85.8 \mathrm{ng} / \mathrm{mL}$. All laboratory tests evaluating liver enzymes, kidney function was within the normal range. The other laboratory test showed in Table 1.

On April $16^{\text {th }} 2020$, the respiratory rate was increased to $36 /$ minutes, while oxygen saturation was $97 \%$ and $5 \mathrm{~L} /$ minute of oxygen via nasal cannula was required. The second swab test was still positive for SARS-CoV-2 infection.

On April $18^{\text {th }} 2020$, the respiratory symptoms were improved, while the third swab test was negative for SARS-CoV-2 infection. Physical examination revealed that the pulse rate was $70 /$ minute, blood pressure of $120 / 60 \mathrm{~mm} \mathrm{Hg}$, respiratory rate of 20/ minute, and the body temperature of $36.2^{\circ} \mathrm{C}$. 
Table1. Clinical manifestation, laboratory profiles, and the treatment process

\begin{tabular}{|c|c|c|c|c|c|c|c|c|c|c|c|}
\hline Results & Referrence & $\begin{array}{l}\text { Day } 1 \\
13 / 4 / 20\end{array}$ & $\begin{array}{l}\text { Day } 2 \\
14 / 4 / 20\end{array}$ & $\begin{array}{l}\text { Day } 3 \\
15 / 4 / 20\end{array}$ & $\begin{array}{l}\text { Day } 4 \\
16 / 4 / 20\end{array}$ & $\begin{array}{l}\text { Day } 5 \\
17 / 4 / 20\end{array}$ & $\begin{array}{l}\text { Day } 6 \\
18 / 4 / 20\end{array}$ & $\begin{array}{l}\text { Day } 7 \\
19 / 4 / 20\end{array}$ & $\begin{array}{l}\text { Day } 8 \\
20 / 4 / 20\end{array}$ & $\begin{array}{l}\text { Day } 9 \\
21 / 4 / 20\end{array}$ & $\begin{array}{l}\text { Day } 10 \\
22 / 4 / 20 \\
\end{array}$ \\
\hline Respiratory rate & & $30 / \mathrm{mnt}$ & $30 / \mathrm{mnt}$ & $30 / \mathrm{mnt}$ & $36 / \mathrm{mnt}$ & $36 / \mathrm{mnt}$ & $20 / \mathrm{mnt}$ & $20 / \mathrm{mnt}$ & $20 / \mathrm{mnt}$ & $20 / \mathrm{mnt}$ & $18 / \mathrm{mnt}$ \\
\hline $\begin{array}{l}\text { Body } \\
\text { Temperature }\end{array}$ & & $36.2^{\circ} \mathrm{c}$ & $36.2^{\circ} \mathrm{c}$ & $36.0^{\circ} \mathrm{c}$ & $36.0^{\circ} \mathrm{c}$ & $36.0^{\circ} \mathrm{c}$ & 36.2 & $36.1^{0} \mathrm{c}$ & $36.2^{\circ} \mathrm{c}$ & $36.0^{\circ} \mathrm{c}$ & $36.0^{\circ} \mathrm{c}$ \\
\hline Saturation & & $98 \%$ & $98 \%$ & $98 \%$ & $97 \%$ & $97 \%$ & $99 \%$ & $99 \%$ & $99 \%$ & $99 \%$ & $99 \%$ \\
\hline Oxygen Therapy & & $3 \mathrm{~L}$ & $3 \mathrm{~L}$ & $3 \mathrm{~L}$ & $5 \mathrm{~L}$ & $5 \mathrm{~L}$ & $5 \mathrm{~L}$ & $3 \mathrm{~L}$ & - & - & - \\
\hline $\begin{array}{l}\text { Electrocardiogram } \\
\text { (ECG) }\end{array}$ & & $388 \mathrm{~ms}$ & - & - & - & - & - & - & - & $438 \mathrm{~ms}$ & - \\
\hline PCR Sars-Cov & & - & positive & - & positive & - & negative & - & - & negative & - \\
\hline C-reactive protein & $\begin{array}{l}<5.00 \\
\mathrm{mg} / \mathrm{dL}\end{array}$ & 5.45 & - & - & - & - & - & - & - & - & - \\
\hline D-Dimer & $<0.5 \mathrm{mg} / \mathrm{L}$ & 0.6 & - & - & - & - & - & - & - & - & - \\
\hline Uric acid & $\begin{array}{l}2.0-7.0 \\
\mathrm{mg} / \mathrm{dL}\end{array}$ & 4.8 & - & 6.2 & - & - & - & 8.2 & - & - & - \\
\hline Oxygen Therapy & & $3 \mathrm{~L}$ & $3 \mathrm{~L}$ & $3 \mathrm{~L}$ & $5 \mathrm{~L}$ & $5 \mathrm{~L}$ & $5 \mathrm{~L}$ & $3 \mathrm{~L}$ & - & - & - \\
\hline \multirow[t]{2}{*}{ Antiviral } & & Favp & Favp & Favp & Favp & Favp & Favp & Favp & - & - & - \\
\hline & & HCQ & HCQ & $\mathrm{HCQ}$ & HCQ & HCQ & HCQ & HCQ & HCQ & HCQ & HCQ \\
\hline Adverse effect & & - & - & - & - & - & - & $\begin{array}{l}\text { Hyperu } \\
\text { ricemia }\end{array}$ & - & - & - \\
\hline
\end{tabular}

Favp: Favipiravir; HCQ: Hydroxyl-chloroquine

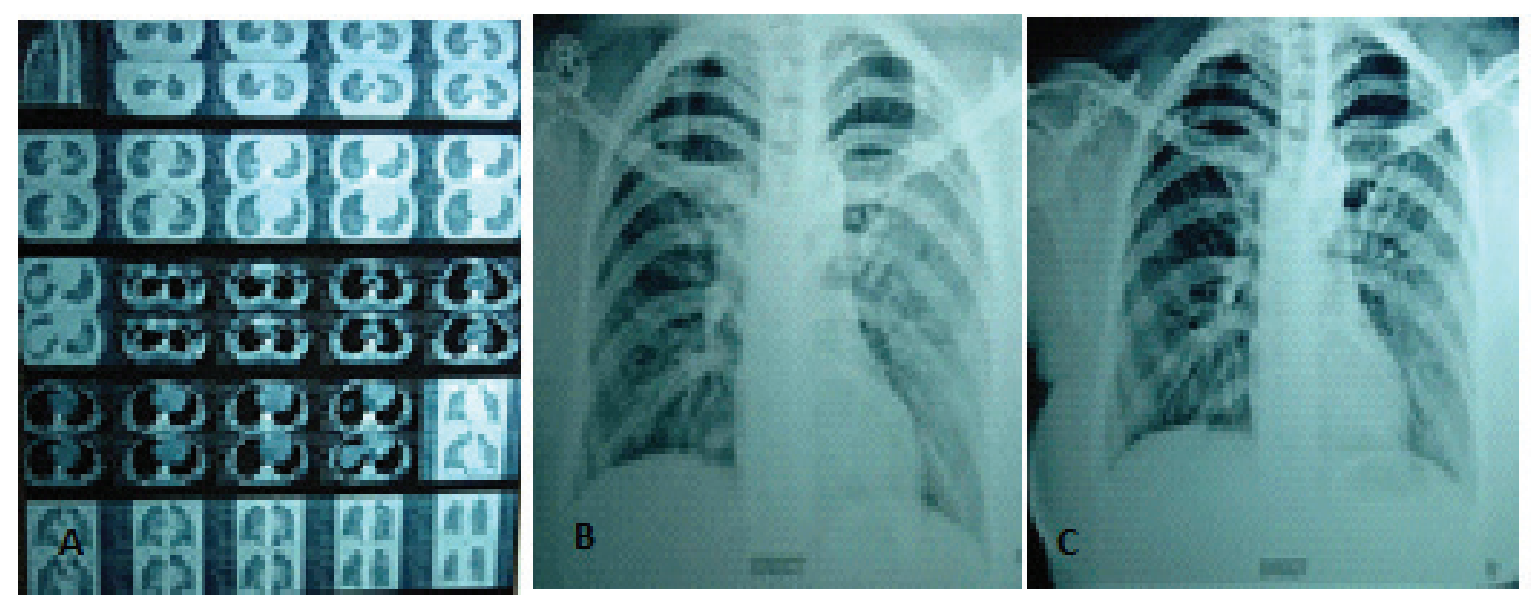

Figure 1. Chest computed tomography (CT) scans and chest X-ray

A. CT scan on Day 1 of hospitalization $(13 / 4 / 20)$

B. Chest X-ray on Day 4 of hospitalization $(16 / 4 / 20)$

C. Chest X-ray on Day 10 of hospitalization (22/4/20)

She was treated with Favipiravir (1600 mg b.i.d on the first day, and $600 \mathrm{mg}$ b.i.d afterwards, for 7 days), Hydroxyl-chloroquine (200 mg b.i.d for 10 days), Azithromycin (500 mg single dose for 5 days), $\mathrm{N}$-acetylcysteine (1250 mg single dose for 10 days), Isoprinosine (500 mg q.i.d for 10 days) and others of supportive treatment. Clinical manifestation, laboratory profiles, the treatment process and an adverse effect showed in Table 1.

On April $21^{\text {st }} 2020$, the condition of the patient was improved and the respiratory symptoms disappeared, while 12-lead ECG revealed sinus rhythm with QTc 438 Ms. The last nasopharyngeal swabs were negative for SARS-CoV-2 infection. On the next day, the patient was discharged. However, there was an increase in uric acid level to $8.2 \mathrm{mg} / \mathrm{dl}$.

\section{DISCUSSION}

Healthcare workers experience significant burden from corona virus infections, including SARS-Cov2. ${ }^{4}$ Roger Chou et al, mentioned that certain exposure is 
associated with increased risk. The use of Personal Protective Equipment (PPE) and infection control training are associated with decreased infection risk. ${ }^{4}$ It is still questionable whether the COVID-19 infection acquired by the healthcare workers in Indonesia was obtained in the community or in the workplace, such as the hospital where they were on duty treating the patients.

In this case, the patients initially had an intermittent fever, cough, sore throat, and rhinorrhea which began at approximately 10 days, and then the symptoms progress into the second stage. Siddiqi et al, showed three escalating phases of COVID-19 disease progression. ${ }^{8}$ According to Eastern Virginia Medical School (EVMS) Critical Care COVID-19 Management Protocol, the course of COVID-19 consists of 4 phase: incubation, symptomatic, early pulmonary phase, and late pulmonary phase. ${ }^{9}$ The initial stage which is also known as viral response phase occurs at the time of establishment of disease with non-specific symptoms. In the second stage, the patients develop viral pneumonia and possibly hypoxia and required supplemental oxygen. ${ }^{8}$ During the second stage of established pulmonary disease, the patient needs to be observed closely and managed wisely. The onset of fever and respiratory symptoms should also be closely monitored by healthcare workers. ${ }^{8}$ Healthcare workers with fever and/or respiratory symptoms that are concerning for COVID-19 should be tested for SARS-CoV-2 as soon as possible. ${ }^{10}$

The patient was treated with favipiravir tablets combine with hydroxychloroquine in the treatment of pneumonia COVID-19. Mechanisms of action of hydroxyl-chloroquine are blockade viral entry by inhibiting glycosylation of host receptors, proteolytic processing and endosomal acidification. ${ }^{5}$ This was followed by Favipiravir that selectively inhibits RNA polymerase, which is necessary for viral replication. ${ }^{5}$ In addition, other drugs supported as a local standard of care (azithromycin, isoprinosine and other supportive treatment) for this infection. The time of improvement or recovery of respiratory symptoms and a negative swab test result was 6 days. In this case, isoprinosine was used to control of a viral infection involves the complex interplay between diverse cell types associated with Natural Killer (NK) cells. ${ }^{11}$ Isoprinosine as an off-label drug in some countries. ${ }^{11}$

However, this case was the first moderate case of COVID-19 treated with favipiravir to a healthcare worker patient on April, in our hospital. We know that the last update stated hydroxyl-chloroquine had small or no effect on overall mortality, initiation of ventilation and duration of hospital stay in hospitalized patients. ${ }^{12}$ By November 2020, the Food and Drug Control Agency of Indonesia revoked hydroxyl-chloroquine and chloroquine authorization for COVID-19 patient treatment. The number of clinical trials on favipiravir and other antiviral for COVID-19 has been increasing day by day especially in Indonesia. However, more evidence of the efficacy and safety of favipiravir are needed, while favipiravir seems to be safe and tolerable in short-term use. ${ }^{13}$

Hyperuricemia was detected in our patient. An adverse effect may be caused by administration of favipiravir that was assessed based on the Naranjo Probability Scale and WHO causality assessment scale. According to the scales of a causal, relationship between medication and adverse effect was probable. ${ }^{14}$ Chang Chen et al showed that there were 32 adverse effects cases from 116 subjects in favipiravir group. Raised serum uric acid (16\%) were common in patients of Favipiravir group. ${ }^{1,15}$ A recent review by Mishima et al revealed that favipiravir may increase blood uric acid level due to the reduction in uric acid excretion into the urine. ${ }^{12}$ The clinicians should be more cautious when favipiravir was prescribed to patients with a history of gout, hyperuricemia, or kidney dysfunction.

Azithromycin, hydroxyl-chloroquine, favipiravir, could cause adverse effects, including QTc prolongation. ${ }^{16-18}$ Therefore, the patient needed close monitoring during concomitant those drugs. In this case, after 7-day treatment, there was an increase in QTc interval $(50 \mathrm{~ms})$. The increase in the QTc interval was still within normal QTc values. However, we could not assume that there was no potential adverse cardiac effect due to the limitations of this single case report. The intensity of QT and arrhythmia monitoring should be considered in the context of potential drug benefit and safety. ${ }^{19-22}$ Furthermore it is necessary to identify patients who have a risk of developing cardiotoxicities by their medical history such as history of heart disease, hypertension, obesity, diabetes, dyslipidemia, physical inactivity, or smoking. ${ }^{23}$

In conclusion, this case presented the first healthcare worker patient with a moderate type of COVID-19, including first treatment experience with Favipiravir. This case highlights that Considering the use of 
emergency intervention outside of clinical trial in the COVID-19 population, the informed patient consent has been given and the use of emergency intervention was monitored. Particular attention should be paid to early diagnosis, early treatment with close monitoring and also adverse drug reactions when using concomitant medications, because COVID-19 patients with moderate clinical symptoms could fall into a severe or critical case.

\section{Conflict of Interest}

The authors declare that they have no conflict of interset

\section{Funding}

No funding or financial support was received

\section{Ethical approval}

Informed patient's consent has been conducted by a verbal approval. This case is a part of the cohort study that was ethically approved by the Health Research Ethics Committee, National Institute of Health Research and Development (Approval number: LB.02.01/2/KE.335/2020)

\section{Acknowledgment}

We are grateful to our patient and other doctors, also nurses of Sulianti Saroso Infectious Disease Hospital who contributed to this case report.

\section{REFERENCES}

1. Chang C, Jiangying $\mathrm{H}$, Zhenshun $\mathrm{C}$, Jianyuan $\mathrm{W}$, Song C, Yongxi Z. et al. Favipiravir versus Arbidol for COVID-19: a randomized clinical trial. [cited: May 2, 2020]. Available from https://doi.org/10.1.10 1/2020.03.17.200337432.

2. World Health Organization. WHO Indonesia COVID-19 situation report-4. [cited: May 2, 2020]. Available from: https://who-int/Indonesia

3. Apriadi. More Indonesia doctors, nurses die fighting against COVID-19. [cited: May 20, 2020]. Available from: https://thejakartapost.com.

4. Rogers C, Tracy Dana, David B, Schelley S, Rongmei F, Annette M. Epidemiology of and risk factors for coronavirus infection in health care workers. ASP Journal. 2020;1632.

5. James MS, Marguerte LT, James B. Pharmacologic treatment for coronavirusdisease 2019 (COVID-19). JAMA. 2020; E1-E5.

6. Zarir FU, Pawan S, Hanmant B, Saiprasad P, Shabbir
R, Amol P, et al. Efficacy and safety of favipiravir, an oral RNA-dependent RNA polymerase inhibitor, in mild-to-moderate COVID-19: a randomized, comparative, open-label, multicenter, phase 3 clinical trial. International Journal of Infectious Diseases. 2020;103:62-71.

7. World Health Organization. Monitored emergency use of unregistered and experimental interventions (MEURI). [cited: March 20, 2021]. Available from: http://www.who.int/ethics/publications/infectiousdisease-outbreaks/en/.

8. Siddiqi HK, Mehra MR. COVID-19 illness in native and immunosuppressed states: a clinical-therapeutic staging proposal. Jhltonline. 2020:405-07.

9. Eastern Virginia Medical School (EVMS) Medical Group. EVMS Critical Care COVID-19 Management Protocol. [cited: May 6, 2020]. Available from: https://www.evms.edu/covidcare

10. Minnesota Department of Health. COVID-19 recommendation for health care workers. [cited: March 16, 2021]. Available from: https://www.health. state.mn.us.

11. Ji`rí B, Marian ŠV`era K, Alena H, Jan M,Jana FR, Ji ‘rí S. Nosine pranobex significantly decreased the case-fatality rate among PCR positive elderlywith SARS-CoV-2 at three nursing homesin the Czech Republic. Pathogens. 2020;9:1055. doi:10.3390/ pathogens 912105

12. Mishima E, Anzai N, Miyazaki M, Abe T. Uric acid elevation by favipiravir, an antiviral drug. Tohoku J Exp Med. 2020;251(2):87-90.

13. Eroglu E, Toprak C. Overview of favipiravir and remdesivir treatment for COVID-19. Int J Pharm Sci \& Res. 2021;12(4):1950-57. doi: 10.13040/ IJPSR.0975-8232.12(4).1950-57.

14. Badan POM RI. Pedoman Monitoring Efek Samping Obat (MESO) bagi tenaga kesehatan. Direktorat Pengawasan Distribusi Produk Terapetik dan PKRT Badan POM RI. Jakarta; 2012. Indonesian.

15. Kaur RJ, Charan J, Dutta S, Sharma P, Bhardwaj P, Sharma P, et al. Favipiravir use in COVID-19: analysis of suspected adverse drug events reported in the WHO database. Infection and Drug Resistance. 2020;13:4427-38.

16. Chief Investigators of the Randomised Evaluation Of COVID-19 Therapy. No clinical benefit from use of hydroxychloroquine in hospitalised patients with COVID-19 - RECOVERY Trial n.d. [cited: March 20, 2021]. Available from: https://www.recoverytrial. net/news/statement-from-thechief-investigators-ofthe-randomised-evaluation-of-covid-19-therapyrecoverytrial-on-hydroxychloroquine-5-june-2020no-clinical-benefit-from-use of hydroxychloroquinein-hospitalised-patients-with-covid-19.

17. Niyada N, Sorin L, Thoetchai P. Cardiac safety of offlabel COVID-19 drug therapy: a review and proposed monitoring protocol. Eur Heart J Acute Cardiovasc Care. 2020;9:215-21. 
18. Pilkington V, Pepperrell T, Hill A. A review of the safety of favipiravir - a potential treatment in the COVID-19 pandemic?. J Virus Erad. 2020;6(2):45-51.

19. Ventricular arrhythmia risk due to hidroxychloroquineazithromycin treatment for COVID-19. [cited: May 3, 2020]. Available from https://www.acc.org/latestin-cardiology/articles/ 2020/03/27/14/00.

20. Ghasemiyeh P, Borhani-Haghighi A, Karimzadeh I, et al. Major neurologic adverse drug reactions, potential drug-drug interactions, and pharmacokinetic aspects of drugs used in COVID-19 patients with stroke: a narrative review. Ther Clin Risk Manag. 2020;16:595-605.
21. Uppsala Monitoring Centre: WHO Programme for International Drug Monitoring. VigiBase. Overview of pharmachovigilance [cited: Nov 28, 2020]. Available from: http://www.lmi.no/download. php? file=/wp-content/uploads/2020/11/UMCoverview-handouts.pdf

22. Uppsala Monitoring Centre. VigiBase: signaling harm and pointing to safer use. [cited: Nov 28, 2020]. Available from: https://www.who-umc.org/vigibase/ vigibase/vigibase-signalling-harm-and-pointing-tosafer-use/.

23. Kelleni MT, Mahrous A. Drug induced cardiotoxicity: mechanism, prevention and management cardiotoxicity. Wenyong Tan, Intech Open. 2018. DOI: 10.5772/intechopen.79611. 